\title{
The Importance of Logistics Efficiency on Customer Satisfaction
}

\author{
Jasminea Burity \\ American Military University
}

Logistics efficiency pertains to how effectively a business conducts operations, and it has a significant impact on internal processes, industry reputation, business revenue growth, and customer satisfaction. Customer satisfaction is crucial for companies because it provides them with a metric that can be used to manage and improve the business and customer experience. To achieve efficient logistics, enterprises need concrete plans for improving existing procedures and developing new ones to maintain success. Companies can monitor with metrics and data analytics, the key performance indicators. Using metrics, measuring the processes, operations, and improving them continuously, leads to intelligent business decisions, better cost control, more revenue, and more profitability. The purpose of this research is to examine and assess the importance of logistics efficiency on customer satisfaction. Key research findings in logistics efficiency and performance, service quality, customer service, and satisfaction are noted. Views and research outcomes of field leaders are identified and assessed. The research confirmed a relationship between logistics efficiency, customer's perceived quality, and the level of customer satisfaction and a relationship between customer satisfaction, customer loyalty and profitability.

Keywords: logistic efficiency, service quality, customer satisfaction, profitability, COVID-19, customer satisfaction measurement, efficiency measurement

\section{INTRODUCTION}

"The marketplace isn't what it used to be" (Kotler, 2000, pp.14).

Since the beginning of the "customer service revolution" almost 25 years ago, business research has focused on customers, especially customer satisfaction. Business consultants, corporations, and operational management have all worked together to identify the characteristics of organizations that consistently please their customers, develop tools that monitor customer satisfaction, and build continuous quality improvement systems that respond to consumer feedback (Ghoumrassi \& Tigu, 2017).

Improving the quality of logistics service is particularly important because it increases customer satisfaction, which heightens the occurrence of strategic partnering and corporate profitability. Unfortunately, an A.T. Kearney logistics study indicates that only about 10 percent of companies can totally satisfy their customers. Increasing attention, however, is being paid to the aspects of logistics policy that can increase customer satisfaction. An important determinant of customer satisfaction is how well the product performs. Since the significant players are each striving to gain market share, product performance becomes similar. 
Similarly, price parity can be achieved with amazing speed. Since high levels of logistics services are not easily copied and are sometimes ignored as a competitive tool, they can be successfully used to develop a sustainable competitive advantage (Sharma, Grewal, \& Levy,1995).

This study seeks to answer the following questions: What connects logistics efficiency, customer service quality, and customer satisfaction levels? What role, companies' logistics strategies play on the overall customer experience and satisfaction? How does customer satisfaction impact loyalty and retention, and what are its relationships to profitability?

\section{LITERATURE REVIEW}

The principal concepts of logistics efficiency, logistics service quality, customer satisfaction, loyalty, customer and logistics performance measurement, logistics, and supply chain management efficiency drove the literature review. Many disciplines were consulted to obtain as comprehensive a picture of the concepts as possible. For developing the research, study information was collected from various primary and secondary peer-reviewed sources and databases such as AMU library Databases, Google Scholar, Academic Journals, Web of Science (Core Collection), Academic Search Ultimate, SCOPUS, Business Source Ultimate.

Logistics management provided the basis for research in logistics service quality and efficiency, and performance. Marketing and economics provided the foundation for developing customer satisfaction, loyalty, and profitability relationship and contributed to analyzing different customer satisfaction measurement tools. The customer service literature also provided the basis for developing the customer satisfaction construct. Each of these literature domains was included to provide a comprehensive review of the extant research that supports the research questions described in the introduction.

Novack et al. defined logistics as an activity that involves managing facilities, transportation, meeting the third party's needs, and information within a company. Saura et al. affirmed that logistics that provide the best quality to customers would offer more significant customer satisfaction and loyalty (as cited in Restuputri, Indriani \& Masudin, 2021).

Logistics efficiency is defined by how smoothly an enterprise or business performs its operations (Andrejić, 2013). Information management systems are used by enterprises, whereby information is collected, identified, analyzed, and distributed within an organization so that decisions can be made and customers served (Information Management Systems, 2017).

Customer satisfaction is a crucial concept in modern marketing thought and practice, emphasizing delivering satisfaction to customers and obtaining profits in return (Yi, \& Nataraajan, 2018). An external customer is a customer who purchases a company's products or services but is not an employee or part of the organization (External Customer, n.d). Farner, Luthans, \& Sommer (2001) acknowledged that the basic principle of internal customer service posits that every department in an organization exists to serve someone, whether that be the external customer or another department. Ullah (2013) noted that it is essential that, to satisfy external customers, internal customers are delighted first. Customer service guides to customer satisfaction, whereas internal customer service guides to employee satisfaction.

As logistics capabilities can raise customer service levels, firms are placing more reliance on logistics service in recent years to improve their competitive positioning (Daugherty, Stank, and Ellinger 1998). Mentzer, Flint, and Hult (as cited in Davis, 2006, p. 133) noted that, while traditional logistics service research focused on "hard" measures to assess customer requirements (e.g., fill rates, on-time delivery, order cycle time), developing "customer-focused" logistics service quality (LSQ), means understanding service from the customer's perspective, which can enhance service offerings and be a tool for differentiation.

\section{THESIS STATEMENT}

Logistics efficiency plays a significant role in the customer experience, loyalty and retention both directly and indirectly, and overall customer satisfaction. 


\section{CUSTOMER SATISFACTION}

\section{Customers}

When assessing drivers of customer satisfaction in a business-to-business context, two different kinds of drivers of customer satisfaction can be identified: factors that affect customers directly and factors that affect employees and therefore affect customer satisfaction (Evanschitzky, Sharma, \& Prykop, 2012). The lack of close attention to internal supplier-customer relationships can jeopardize external customer satisfaction. Companies must ensure that all customers are satisfied - both within and outside of the firm (Pfau, Detzel, and Geller,1991).

Although logistics service entails enhancing services and reducing costs, understanding logistics from the customer's perspective can enhance the service offerings and be a tool for differentiation (Mentzer, Flint, and Hult 2001). In understanding customer's expectations of service, firms can focus on those elements of service that will make the most significant impact in terms of influencing future behavior.

\section{Internal Customers and External Customers}

Novikova (2006) affirmed that the customers' perceptions of the service quality and their satisfaction with the service mainly depend on the interaction with the employee. Berhnardt et al., Koys, and Tornow \& Wiley proved a positive association between employee and customer satisfaction. Wangeheim, Evanschitzky, \& Wunderlich perceived quality and the perceived price had the most considerable effect on customer satisfaction. Still, employee job satisfaction was also proven to be a statistically significant factor (as cited in Novikova, 2006).

The basic assumption is that if everybody strives to provide their "internal customer "with better service, then the end customer will receive higher quality service. (Farner, Luthans, \& Sommer, 2001, p.350). External customers are essential to any business as they provide a revenue stream, make repeat purchases and refer your products to other people (External Customer, n.d).

According to Muhlemann et al. (as cited in Croom \& Johnston,20,03), for an organization to be truly effective, every single part of it, each department, each activity, and each person and each level, must work properly together because every person and every activity affects and in turn is affected by others.

Cook (as cited in Ullah, 2013) noted that the value of service distributed to the external customer is often established by the value of service that internal customers - employees - provide each other. It is essential to keep in mind that every person within a firm offers a service (Ullah, 2013).

\section{Customer Expectations}

According to Chen, Huang, Hsu, Tseng, \& Lee (as cited in Querin, \& Göbl, 2017, p. 92), customer expectations influence customer satisfaction and retention, confirming the original expectations been identified as the most influential factor of satisfaction. Research by La Londe \& Masters (as cited in Querin, \& Göbl, 2017, p. 93) observed that the increase in inventory management capability and efficiency might have impacted the customers' expectations.

\section{Customer Satisfaction Considerations for Businesses}

Customer satisfaction is an essential component of a successful and profitable organization. It gives rise to higher profit margins and greater employee satisfaction, customer loyalty, and retention; thus, it should become the cornerstone to all other business performance metrics.

Several studies related to the logistics service quality conducted by Lisińska-Kuśnierz and Gajewska explained that companies must get customer satisfaction and loyalty by evaluating the timeliness, completeness, and accuracy in delivery (as cited in Restuputri, Indriani \& Masudin, 2021). Key considerations are:

\section{Customer Loyalty and Retention}

Mittal and Lassar (as cited in Davis, 2006) stated that customer loyalty is increasingly recognized as a path to long-term success because finding new customers and doing business with them takes time, effort, 
and money. Fay also asserted that achieving the customer-loyalty rate objective has become as important as achieving any other financial or strategic objective.

Several pieces of research (Hennig-Thurau, Gwinner and Gremier 2002; Gould 1995; Mcllroy and Barnett 2000; as cited in Davis, 2006) have supported the prediction that customer loyalty positively affects profitability. Flint and Mentzer acknowledged that as suppliers in dynamically competitive markets try to find ways to retain strategically important business, customers firms can positively impact customer loyalty by providing outstanding logistics service.

\section{Customer Profitability}

The development of strategic partnerships through satisfied customers facilitates an increase in sales and reduced costs. Satisfied customers are less sensitive to price than either dissatisfied customers or new customers, and they are more willing to pay for the services they receive. Thus, it is prudent to cultivate satisfied customers. Several empirical studies have shown a positive link between customer service and profitability. (Sharma, Grewal, \& Levy, 1995, p.12)

\section{Customer Service Experience}

Kempny (as cited in Kułyk, Michałowska \& Kotylak, 2017) includes the following elements of customer service in logistics: delivery time, product availability, the flexibility of delivery, frequency of delivery, delivery reliability, delivery completeness and accuracy, the convenience of placing orders, as well as the convenience of documentation when submitting orders. Novack, Langley, and Rinehart (as cited in Davis, 2006, p.30) noted that when buyers can select similar products from several suppliers, sellers may choose to differentiate themselves by the quality of their customer service and by the service processes accompanying their products.

\section{Complaint Management}

Some firms don't like to hear complaints from their customers. Ironically those who complain and have their problems resolved will tend to be more satisfied, have higher repeat purchase behavior, and generate more positive word-of-mouth publicity than customers whose complaints weren't resolved or who did not complain in the first place. Therefore, it is in the best interest of selling firms to encourage complaints by setting up formal and informal feedback systems. Of course, the satisfactory resolution of complaints is critical to customer satisfaction (Sharma, Grewal, \& Levy, 1995, p.13).

\section{LOGISTICS EFFICIENCY}

\section{Importance of Logistic Efficiency on Customer Satisfaction}

Efficiency is a very important indicator of the analysis of companies' operations (Andrejić, 2013). Competitive advantage can be gained by a company that finds ways of performing strategically logistics activities, or ensuring that these activities are performed, more efficiently than its competitors. Effective and efficient logistics management can provide a significant source of competitive advantage to a company.

Ways to enhance logistic efficiency and improve customer experience/relations include having information management systems, logistics service quality and capabilities, logistics reliability, staff training programs, and learning from the competition.

Customers have expectations of logistics service performance before they buy the product (prepurchase expectations), and logistics managers should determine customers' initial (precontact) logistics performance expectations and monitor their own service levels as well as those of competitors (Sharma, Grewal, \& Levy, 1995).

\section{Impacts of Covid-19 Pandemic on Logistics Service Quality and Efficiency on Customer Satisfaction}

COVID-19, a novel coronavirus disease caused by severe acute respiratory syndrome coronavirus 2 (SARS-CoV-2), was identified in December 2019 in the capital of Hubei province, the most populous city 
of Central China, Wuhan (WHO, 2020), and become a global pandemic due to its rapid and massive spread and contagiousness, fatality rates, and lack of effective vaccines or treatments.

To deal with the pandemic, lockdowns, social distancing, self-quarantine, and working from home were recommended in all countries to stop the spread of the virus. These and other guidelines were followed, schools and businesses were closed, and issuing calls to stay at home were made. These sudden and unprecedented shutdowns led to significant supply chain and logistics demands, extreme challenges, and logistics companies directly affected by the COVID-19 pandemic.

Disruptions to the logistics sector caused by the pandemic impacted competitiveness, economic growth, and job creation. Lockdowns make the logistics system hampered, decreasing customer satisfaction and loyalty to logistics service providers (Biswas \& Das, Tedjakusuma et al., as cited in Restuputri, Indriani \& Masudin, 2021). The efficiency of all the logistics and supply chain management (LSCM) operations, especially during pandemics, has played a crucial role (Arinaminpathy \& McLean; Jennings et al. as cited in Illahi \& Mir 2020).

The importance of maintaining efficient LSCM and logistical issues has also been recognized by the world's leading organizations like WHO in its activity Report (WHO,2012): "to provide operational assistance in the ongoing management of logistics required for epidemic and pandemic preparedness and response and the rapid deployment of medical and laboratory supplies, transport, communications as well as the rapid deployment of outbreak response teams."

The resulting lockdowns, shelter-in-place orders, and consumers increased desire to stay at home have caused a shift in buying behavior among consumers, accounting for the rise of online shopping. The supply chain has faced fulfillment challenges from this influx of online orders, along with a myriad of crisis-related disruptions, including long wait times at warehouse depots, truck driver shortages, altered trucking routes. These issues have impacted consumers' experiences and, ultimately, their expectations. Supply chain operations significantly impact customer satisfaction, especially for e-commerce orders, and a few factors in particular influence customer satisfaction for better or worse, including price, delivery speed, and service quality (Frys, 2020).

A study by Udofia, Adejare, Olaore, and Udofia (2021) to examine Covid-19, supply disruption, customer satisfaction, organizational productivity, and performance in the Nigerian manufacturing sector found that the pandemic triggered supply disruptions but did not significantly impact the productivity of manufacturing firms directly. However, supply disruption positively and significantly impacted productivity. Organizational productivity had no significant impact on customer satisfaction; however, it produces a positive indirect effect when mediating the relationship between Covid-19 and customer satisfaction. Finally, Covid-19 and supply disruption, when mediated by organizational productivity, had significant negative relationships on performance. Though customer satisfaction was expected to be affected by the pandemic, it is interesting to find out that customer satisfaction was positively influenced when mediated by organizational productivity.

Leaders must take urgent action to respond to new conditions, support the workforce and sustain business operations, and use this opportunity to reset their operations with digital capabilities and renew their logistics operating models, thus helping increase operational efficiency and effectiveness. By doing so, companies will emerge from the present crisis with more resilient supply chains to future disruptions. For continual logistics efficiency and customer satisfaction, logistics companies should ensure proactive, regular, transparent, and effective communication with onsite and remote workers, suppliers, carriers, and customers. Fulfillment and logistics teams should engage proactively and collaborate with other supply chain functions, suppliers, carriers, customers, and remote workers (Accenture, 2020).

As the journey to recovery begins, some companies are looking to diversify and relocate their supply chains closer to home. Logistics companies fast-tracked their growth and development strategies, quickly expanding to seven days a week and making significant e-commerce, people, and assets investments to cope with demand. There are, therefore, even more intense pressures now on companies to find creative ways to improve delivery density and cost-efficiency (Sharma,2017).

Bain's analysis shows that companies with resilient supply chains grow faster because they can race to meet customers' needs when market demand shifts. They increase their perfect order rate by $20 \%$ to $40 \%$ 
and customer satisfaction by as much as $30 \%$. Significantly, flexible supply chains cut costs and improve cash flow, in part through a $10 \%$ to $40 \%$ increase in inventory turns. Finally, leaders reduce disruption by building buffers throughout the supply network and invest in advanced analytics to improve planning and forecasting accuracy (Schatteman, Woodhouse, \& Terino, 2020).

\section{LOGISTICS EFFICIENCY AND CUSTOMER SATISFACTION MEASUREMENTS}

Efficiency is the ratio of resources utilized against the results derived (Mentzer \& Konrad, 1991). According to Andrejić (2013), measuring efficiency in logistics is a complex process that requires consideration of all subsystems, processes, and activities as well as the impact of various financial, operational, environmental, quality, and other factors.

From the point of time and the significance of the decision-making, there are three hierarchical levels of efficiency measurement: strategic, tactical, and operational level. Following the mentioned aspects, it is possible to differentiate the following efficiency measurement aspects in logistics: activities efficiency, processes efficiency, subsystems efficiency, systems efficiency, and supply chain efficiency.

Andrejić (2013) stated that in addition to monitoring and measuring the efficiency in logistic systems (freight forwarding, logistic centers, distribution centers, warehouses, etc.), it is necessary to analyze the efficiency of logistics activities and processes in systems whose primary function is not logistic services (retail chains, hospitals, etc.).

For a successful measurement of efficiency in logistics, it is necessary to consider a large number of inputs and outputs different in nature. Financial, technical, environmental, energy, social, and many other factors expressed in different units influence efficiency in logistics. The efficiency of supply chains and logistics systems is also affected by many factors upon which the company management has no influence, such as weather conditions, market situation, competition behavior, etc.

\section{Measuring Customer Satisfaction and Logistics Efficiency}

Customer satisfaction measures how the products and services provided by a company meet or exceed customer expectations (Ellinger et al.,2011). There are several ways to measure customer satisfaction level as follow:

\section{SERVQUAL Model}

SERVQUAL measures the gap between the level of service a customer would expect to receive from an "excellent "company versus the level of service they are receiving from the target company (Farner, Luthans, \& Sommer, 2001, p. 355). Shahin (2004) acknowledged that the SERVQUAL instrument had been the predominant method used to measure consumers' perceptions of service quality. Van Iwaarden et al. (as cited in Shahin, 2004, p.4) noted five generic dimensions or factors: tangibles, reliability, responsiveness, assurance, and empathy.

\section{The Kano Model}

As per Ma, Chen, and Chang (as cited in Gani, Dewanti, Irawan, \& Bastarianto, 2018, p.214), The Kano Model is used to study each nature of the customer needs, providing a way to better classify customer needs.

Herbowo (as cited in Gani et al., 2018, p.214) noted that The Kano model aims to categorize the service attributes based on how well the service can provide satisfaction to consumer needs, and Yao, Chuang, and

Hsu stated that The Kano model is divided into six categories based on service characteristics and level of the customer's satisfaction, namely: must be one dimensional, attractive, indifferent, reserve, and questionable. 


\section{Customer Satisfaction Indexes(CSI)}

Since the 1970s, researchers of consumer behavior and marketing in developed countries have begun to conduct comprehensive studies on customer satisfaction (Oliver,1977; Churchill and Suprenant,1982; Olshavsky,1993; as cited in Yang, Tian, \& Zhang, 2005, p. 1).

In the 1990s, CSI was gradually recognized by governments and companies worldwide as an excellent instrument to gauge a nation's or company's output quality. Nation-level CSIs that exist are from Sweden (SCSB), USA (ACSI), Germany, Norway (NCSB), Switzerland (SWICS), South Korea Customer (KCSI), and Malaysia (MCSI) (Yang, Tian, \& Zhang, 2005, p.1). The European Organization for Quality, Foundation for Quality Management, Academic Network for Customer-Oriented Quality Analysis, and the

European Commission developed the European Customer Satisfaction Index (ECSI) (Aydin \& Özer, 2005).

CSIs are fundamentally similar in measurement models but have some apparent distinctions in Model's structure and variable selection so, their results cannot be compared with each other. The most sophisticated and influential CSI systems are the ACSI, ECSI, NCSB, and SWICS (Yang, Tian, \& Zhang, 2005, p. 1).

\section{Customer Satisfaction/Feedback Surveys and Questionnaires}

Several metrics have been developed to understand the relationship between the company and the customer. Some of the most popular techniques for measuring the strength of the relationship between the company and its customers are Customer Satisfaction (CSAT), Net Promoter Score (NPS), and Customer Effort Score (CES) (Bleuel,2019). In a Kaikkonen (2018) study, they are defined as follow:

- CSAT is an important key performance indicator (KPI) that allows companies to track their customer satisfaction in real-time by measuring how satisfied the customer is after receiving a service or product.

- CES calculates the effort a customer puts into a certain interaction with a company. From the purchasing decision to finding the product (or service) and then buying it.

- Reichheld (as cited in Kaikkonen, 2018) affirmed that NPS is a KPI that measures a customer's willingness to recommend a product or service to family, friends, and colleagues.

Companies constantly have to measure and monitor their performances and define appropriate corrective actions to stay in the market. One of the basic and frequently used performances is efficiency, and it is a very important indicator of the analysis of companies' operations (Andrejić, 2013).

\section{CONCLUSION}

The logistics activities within a business organization attempt to satisfy customers by achieving the time and location-related market challenges and the cost of the service provided, and the quality, taking into consideration customers' needs and purchasing power. Customer satisfaction is important because it provides marketers and business owners with a metric that they can use to manage and improve their businesses and is a way to determine the continuity of the business or a product life by measuring the loyalty of the customers (Ghoumrassi \& Tigu, 2017).

Customer dissatisfaction is caused mainly by poor service and providers not providing new service improvements but still using the same model as before. Service providers feel that the services used are acceptable to customers but no longer meet customer expectations because of increasing market competition and changing customer tastes (Rust \& Zahorik, as cited in Restuputri, Indriani \& Masudin, 2021).

Several studies (Anderson, Fornell and Lehmann, 1994; Ittner and Larcker, 1996; and Fornell et al.,2006; Oliva et al.,1992; as cited in Ellinger et al., 2012, p.251) showed that firms with higher levels of customer satisfaction generate higher returns on investment, productivity, market value-added, shareholder value, and stock market performance. Furthermore, they affirmed that increasing and maintaining high levels of customer satisfaction enhances customer loyalty and serves as a safeguard against increasing price competition and the commoditization of products. As supply chain management competency enables firms to create value by better meeting customer service expectations, customer satisfaction increases (Ellinger et al., 2012). 
Hallowell affirmed that loyalty from customers would create increased profit by increasing revenue, lowering costs to attract customer attention, and decreasing price sensitivity, while Gronholdt et al. conducted a study that increased market share can reduce customer satisfaction. It is more difficult to satisfy customers who consist of many segments rather than those with small ones (as cited in Restuputri, Indriani \& Masudin, 2021).

A customer-oriented culture and partnership with customers and suppliers are essential to achieving customer satisfaction and high employee satisfaction (Fečiková, 2004). For logistics and supply chain management, the goal will continue to improve overall efficiency through integrated logistics management and sound logistics decisions, which must lead to the maximization of customer satisfaction and the lowest possible total cost. In this way, logistics management can contribute significantly to overall company efficiency, competitive advantage, and profitability (Lambert, Stock, \& Ellram, 1998).

In times of crisis, a customer's interaction with a company can trigger an immediate and lingering effect on his or her sense of trust and loyalty. Now is the time for customer experience leaders to position themselves at the forefront of the longer-term shifts in consumer behavior that result from this crisis. Customer experience has taken on a new definition and dimension in the overwhelming challenge of COVID-19, and customer leaders who care and innovate during this crisis and anticipate how customers will change their habits will build stronger relationships that will endure well beyond the crisis's passing (Diebner, Ungerman, Silliman \& Vancauwenberghe, 2020).

The COVID-19 pandemic crisis has tested the resilience and flexibility of distribution networks and logistics operations worldwide. Leaders should use this time of disruption to reset, rethink and renew logistics and SCM for the long-term benefit of their businesses and the communities they serve. Companies should reset operations by conducting a detailed analysis of the response phase, revisiting master contracts and customer channel segmentation and logistics agreements, realigning the existing workforce as needed, and decide which digital technologies used during the crisis could be adopted permanently for enhancing capabilities for the long haul. The COVID-19 emergency will pass, and leaders will need to make decisions and take actions that will generate revenue, protect jobs and support the return to growth. Companies should also consider how to renew their logistics operating models to increase resilience, responsibility, effectiveness, and efficiency by adopting a smart zero-based mindset, increasing the maturity of the ecosystem, investing in omni-channel fulfillment platforms, identifying investments in automation and robotics for logistics, driving greater logistics collaboration and building responsibility and trust (Accenture,2020).

\section{REFERENCES}

Accenture. (2020). COVID-19: The road map to resilience through logistics. Retrieved from https://www.accenture.com/us-en/insights/consulting/coronavirus-supply-chain-logisticsresilience

Andrejić, M. (2013). Measuring efficiency in logistics. Vojnotehnički Glasnik, 61(2), 84-104. https://doi.org/10.5937/vojtehg61-1756

Aydin, S., \& Özer, G. (2005). National customer satisfaction indices: An implementation in the Turkish mobile telephone market. Marketing Intelligence \& Planning. Retrieved from https://scholar.google.com/scholar?cluster $=3796513581217239373 \& \mathrm{hl}=\mathrm{en} \&$ as $\mathrm{sdt}=0,33$

Bleuel, W. (2019). CSAT or CES: Does It Matter? Graziado Business Review, 22(1). Retrieved from https://gbr.pepperdine.edu/2019/03/csat-or-ces-does-it-matter/

Croom, S., \& Johnston, R. (2003). E-service: Enhancing internal customer service through eprocurement. International Journal of Service Industry Management. Retrieved from https://scholar.google.com/scholar?hl=en\&as_sdt=0\%2C33\&q=what+is+internal+customer\&btn $\mathrm{G}=$

Daugherty, P.J., Stank, T.P., \& Ellinger, A.E. (1998). Leveraging Logistics/Distribution Capabilities: The Impact of Logistics Service on Market Share. Journal of Business Logistics, 19(2), 35-51. 
Davis, E.R. (2006). The role of logistics service quality in creating customer loyalty. Retrieved from https://scholar.google.com/scholar?hl=en\&as_sdt=0\%2C $33 \& \mathrm{q}=$ the + role + of + logistics + service $+\mathrm{q}$ uality\&btnG=

Diebner, R., Ungerman,K., Silliman, E., \& Vancauwenberghe, M. (2020). Adapting customer experience in the time of coronavirus. Retrieved from https://www.mckinsey.com/business-

functions/marketing-and-sales/our-insights/adapting-customer-experience-in-the-time-ofcoronavirus

Ellinger, A., Shin, H., Northington, W., Adams, F., Hofman, D., \& O’Marah, K. (2012). The influence of supply chain management competency on customer satisfaction and shareholder value. Supply

Chain Management, 17(3), 249-262. https://doi.org/10.1108/13598541211227090

Evanschitzky, H., Sharma, A., \& Prykop, C. (2012). The role of the sales employee in securing customer satisfaction. European Journal of Marketing, 46(3), 489-508.

doi:http://dx.doi.org.ezproxy1.apus.edu/10.1108/03090561211202576

External Customer. (n.d). Retrieved from https://www.mbaskool.com/business-concepts/marketing-andstrategy-terms/14130-external-customer.html

Farner, S., Luthans, F., \& Sommer, S. (2001). An empirical assessment of internal customer service. Retrieved from http://citeseerx.ist.psu.edu/viewdoc/download?doi=10.1.1.545.6990\&rep=rep1\&type=pdf

Fečiková, I. (2004). An index method for measurement of customer satisfaction. The TQM Magazine, 16(1), 57-66. Retrieved from

https://scholar.google.com/scholar?hl=en\&as_sdt=0\%2C33\&q=Feciková\%2C+I.+\%282004\%29. + An + index + method + for + measurement + of + customer + satisfaction. + The + TQM

Frys, P. (2020). Harris Poll Survey: How Supply Chain Operations Impact Customer Satisfaction During Coronavirus and Beyond. Retrieved from https://retailtouchpoints.com/features/executiveviewpoints/harris-poll-survey-how-supply-chain-operations-impact-customer-satisfaction-duringcoronavirus-and-beyond

Gani, M.G., Dewanti, D., Irawan, M.Z., \& Bastarianto, F.F. (2018). Determining Priority Service of Yogyakarta Adisutjipto Airport Using Servqual Method and Kano Model. Journal of the Civil Engineering Forum, 5(3), 211-226. Retrieved from https://journal.ugm.ac.id/jcef/article/view/45364

Ghoumrassi, A., \& Țigu, G. (2017). The impact of the logistics management on customer satisfaction. Proceedings of the International Conference on Business Excellence, 11(1), 292-301. https://doi.org/10.1515/picbe-2017-0031

Illahi, U., \& Mir, M. (2020). Maintaining efficient logistics and supply chain management operations during and after coronavirus (COVID-19) pandemic: Learning from the past experiences. https://doi.org/10.1007/s10668-020-01115-z

Information Management Systems. (2017). In D.D. Johnson, Gale virtual reference library: Encyclopedia of emerging industries (7th ed.). Farmington, MI: Gale. Retrieved from https://searchcredoreferencecom.ezproxy2.apus.edu/content/entry/galeei/information_management_systems/0

Kaikkonen, T. (2018). Satisfaction and sales-cause or correlation? Consumer research \& relationship marketing at WHSmith Helsinki-Vantaa airport (SSP Finland). Retrieved from https://scholar.google.com/scholar?hl=en\&as_sdt=0\%2C33\&q=+CSAT+CES+NPS\&btnG $=$

Kułyk, P., Michałowska, M., \& Kotylak, S. (2017). Assessment of customer satisfaction with logistics service in the light of the results of the research. Management, 21(1), 205-222. Retrieved from https://scholar.google.com/scholar?hl=en\&as_sdt=0\%2C33\&q=Assessment + of + customer + satisfa ction + with + logistics + service + in + the + light + of + the + results + of + the + research.\&btnG $=$

Lambert, D., Stock, J.R., \& Ellram, L.M. (1998). Fundamentals of Logistics Management. Boston, Massachusetts. McGraw-Hill International Editions.

Mentzer, J.T., Flint, D.J., \& Hult, G.T.M. (2001). Logistics service quality as a segment-customized process. Journal of Marketing, 65(4), 82-104. Retrieved from http://citeseerx.ist.psu.edu/viewdoc/download?doi=10.1.1.476.8877\&rep=rep1\&type=pdf 
Mentzer, J.T., \& Konrad, B.P. (1991). An Efficiency/Effectiveness approach to logistics performance analysis. Journal of Business Logistics, 12(1), 33. Retrieved from https://searchproquest-com.ezproxy1.apus.edu/docview/212660593 accountid $=8289$

Novikova, K. (2006). A study of customer satisfaction factors and employee satisfaction in the hospitality industry. Retrieved from https://scholar.google.com/scholar?hl=en\&as_sdt=0\%2C33\&q=Ksenia+Novikova $\% 2 \mathrm{C}+\mathrm{K} . \% 282$ $006 \% 29 .+\mathrm{A}+$ study + of + customer + satisfaction+factors + and + employee + satisfaction + in + the + hospi tality+industry.+B.S.\%2C+Voronezh+State+University\&btnG $=$

Pfau, B., Detzel, D., \& Geller, A. (1991). Satisfy Your Internal Customers. Journal of Business Strategy, 12(6), 9-13. https://doi.org/10.1108/eb039449

Querin, F., \& Göbl, M. (2017). An analysis on the impact of Logistics on Customer Service. Journal of Applied Leadership and Management, 5, 90-103. Retrieved from https://scholar.google.com/scholar?cluster=15755398004128481718\&hl=en\&as_sdt=0,33

Restuputri, D., Indriani, T., \& Masudin, I. (2021). The effect of logistic service quality on customer satisfaction and loyalty using Kansei engineering during the COVID-19 pandemic. Cogent Business \& Management, 8(1), 1906492. DOI: 10.1080/23311975.2021.1906492

Schatteman, O., Woodhouse, D., \& Terino, J. (2020). Supply Chain Lessons from Covid-19: Time to Refocus on Resilience. Retrieved from https://www.bain.com/insights/supply-chain-lessons-fromcovid-19/\#

Shahin, A. (2004). SERVQUAL and Model of Service Quality Gaps: A Framework for Determining and Prioritizing Critical Factors in delivering quality services. Department of Management, University of Isfahan. Retrieved from https://scholar.google.com/scholar?hl=en\&as sdt=0\%2C33\&q=SERVQUAL+and+Model + of + Se rvice + Quality + Gaps $\% 3 \mathrm{~A}+\mathrm{A}+$ Framework + for + Determining + and + Prioritizing + Critical + Factors $+\mathrm{i}$ n. $+\& b \operatorname{tnG}=$

Sharma, A., Grewal, D., \& Levy, M. (1995). The customer satisfaction/logistics interface. Journal of Business Logistics. Retrieved from https://search-proquestcom.ezproxy1.apus.edu/docview/212640877?accountid=8289

Sharma, B. (2017). Logistics: Challenges and opportunities in the post-covid-19 world. Retrieved from https://atos.net/en/blog/logistics-challenges-and-opportunities-in-the-post-covid-19-world

Udofia, E.E., Adejare, B.O., Olaore, G.O., \& Udofia, E.E. (2021). Supply disruption in the wake of COVID-19 crisis and organizational performance: Mediated by organizational productivity and customer satisfaction. Journal of Humanities and Applied Social Sciences. https://doi.org/10.1108/JHASS-08-2020-0138

Ullah, I. (2013). The influence of human resource practices on internal customer satisfaction and organizational effectiveness. Acta Universitatis Danubius. Administratio. Retrieved from https://scholar.google.com/scholar?hl=en\&as_sdt=0\%2C33\&q=The+influence+of + human + resour ce+practices + on + internal + customer+satisfaction+and+organizational+effectiveness $\& b \operatorname{btn}=$

WHO. (2020). Emergencies preparedness, response: Novel Coronavirus-China. Retrieved from https://www.who.int/csr/don/12-january-2020-novel-coronavirus-china/en/

Yang, X., Tian, P., \& Zhang, Z. (2005). A comparative study on several national customer satisfaction indices (CSI). Retrieved from https://scholar.google.com/scholar?hl=en\&as_sdt=0\%2C33\&q=+Swiss + Index + of + Customer + Sat isfaction $+\% 28$ SWICS $\% 29 \& b t n G=$

Yi, Y., \& Nataraajan, R. (2018). Customer satisfaction in Asia. Psychology \& Marketing, 35(6), 387-391. https://doi.org/10.1002/mar.21093 